\title{
Observation of the Disconnection between Real and Financial Spheres: The Case of the Tunisian Stock Market during the Period 1969-2008
}

\author{
Kamel NAOUI (Corresponding author) \\ Department of accounting and finance \\ Ecole supérieure de commerce de Tunis, Tunis \\ Campus Universitaire de la Manouba, la Manouba 2010 \\ Tel: 216-71-602-760Ｅ-mail: Kamelnaoui@gmail.com
}

\author{
Abderrazek ELKHALDI \\ Department of Management and Quantitative Methods, Tunis
}

Faculté de Droit et des Sciences Economiques et Politiques de Sousse-Université de Sousse

Tel: 216-73-690-674Ｅ-mail: Abderrazek.Elkhaldi@enit.rnu.tn

Salem BRAHIM

Institut supérieur d'informatique, Tunis

Université de Tunis El Manar

\begin{abstract}
The strong volatility that characterized financial markets all over the word, these last years, leaves to think the existence of a disparity between stock prices and their fundamental values, which gives us the presumption of a disconnection between the real sphere and the financial one (Binswanger (1999, 2000, 2004 )). The purpose of this paper is to focus on this possible disconnection by using the cointegration tests, to detect a possible equilibrium relation between the stock exchange returns and the real economic activity growth (measured by the GDP). The period of study lies between 1969 and 2008, according to an annual frequency of two series: the real yields (Stock Market Index return) and of GDP growth rates (real economic sphere indicator). To settle on the dynamics of short and long term between the stock exchange returns and the GDP growth, we used the Vector Errors Correction Model (VECM). Our results corroborate the existence of the disconnection between the two financial and economic series.
\end{abstract}

Keywords: Stock market return, Financial bubbles, Real sphere

JEL classification: E30, E44, G10, G12

\section{Introduction}

Stock market prices fluctuations are certainly linked with economic ones, this fact was confirmed by the present financial and economic crisis of October 2008. Theoretically, stock price expectations are based on economic fundamentals. In a macroeconomic level, these anticipations depend largely on market expectation of future economic growth level. Indeed, financial market can be considered as a leading indicator of the economy. Consequently, stock price movement explanation must be held according to economic indicators' fluctuations.

The last few years have been characterized by several speculative accidents that have affected financial market all over the world. Many explanations based on fundamentals have been given essentially by Balke and Wohar (2001), Carlson and Sargent (1997), Heaton and Lucas (2000), Kopcke (1997), McGrattan and Prescott (2000). Contrarily, other authors like Binswanger $(1999,2000,2004)$ and Shiller $(2000)$, think that the stock price fluctuations can not be explained by fundamentals but they are the consequence of exogenous speculative bubbles or an irrational exuberance.

Binswanger $(2000,2004)$ studied the role of real activities in speculative accidents explanation in the case of American market. He found no evidence that real economy would explain these disorders. This finding - opposed to the classic learning of the actualized future cash flow approach considered by Fama (1990) as a reflection of the 
real economy - lead Binswanger $(2000,2004)$ to explain this disconnection by the existence of speculative bubbles or fads.

Moreover, in order to determine if recent fluctuations exhibited by stock prices are governed by fundamentals, we must, according to Binswanger $(2000,2004)$ approach, analyze whether stock prices carry on significant information about real economy growth rate.

According to the future cash flow (dividend) actualization model, stock market prices must reflect investor's anticipations about future real economic activities. Consequently, fundamental value of a stock price will be equal to the actual value of future cash flows or dividends, witch are supposed to be generated by the firm's real economic activity. Therefore, future cash flows must reflect real economic activity apprehended according to Morck, Shleifer and Vishny (1990) and Shapiro (1988) by industrial production or GDP. These aggregates are considered by Choi, hauser and Kopecky (1999) as proxies of firm's earnings or profits.

However, we note that all over the world, major transactions are motivated by speculative intentions independently from fundamentals. This makes us think, à priori, that there is a disconnection between real and financial spheres.

The purpose of this paper is to give and explanation to this disconnection between economic and financial spheres and to detect a possible equilibrium relation between stock market returns and real economic activity growth apprehended by the GDP. In these conditions, this study will be organized as follows: second section explore the literature studying relationship between real and financial spheres. Section three presents our empirical methodology. Section four comments the results. Section five concludes.

\section{Literature review}

Several studies tried to find whether recent stock price fluctuation could be conducted by fundamentals. A first approach analyses the relationship between financial assets returns and economic growth level such as Binswanger's (2000).

By reference to the Discounted Cash Flow approach, stock prices must reflect investor's anticipations of the future economic growth level. Indeed, the fundamental value of a stock market must be equal to the future anticipated actualized dividends. These payments can so reflect the real growth level.

Morck, Shleifer, \& Vishny (1990), Shapiro (1988) maintain that financial assets returns can be used as proxies for firm's earnings and so for economic growth. Binswanger's findings confirmed the strong classical relationship between financial assets returns and their consequences on the real economic growth level. Such relationship was often rejected in the eighties, where all estimations failed to find significant evidences.

This failure was concomitant to the submerging of speculative bubbles all over financial markets and stimulated the non fundamental approach.

Choi and al. (1999) have studied this relationship in the case of the G-7 countries during the period 1957-1996. They have found a significant relationship between financial assets returns and economic level growth for all countries except Italy.

However, this relationship was not the same in all the countries, especially in the case of the USA, where it was less significant compared to the rest of G-7 countries. This can be explained by the size of this economy significantly greater than the others. Then, because firms of those countries deal partially or totally abroad. Hence, investors do not include their national macroeconomic variables in their anticipations. For all these reasons, it seems that it is difficult to confirm this relationship in these countries. It would be more difficult to confirm it in the case of emerging economies.

After the Second World War, the United States has experienced two periods of strong growth in their stock market. The first period lasted from 1949 until the first half of the 60s, and coincided with a period of strong economic growth. At that time, economic research had no problem to demonstrate the relationship between economic and financial spheres, using asset pricing standard models, under which financial asset prices are determined through market fundamentals. However, the second growth period began in the $80 \mathrm{~s}$ and demonstrated how it became difficult to verify that asset prices could still be determined by fundamentals.

If asset prices are determined by fundamentals, it will be possible to predict future economic activity. For example, Shapiro (1988) considers that the fundamental value of the in a company share will equal the present value of expected future dividends, which is simply a reflection of economic activity anticipated evolution, measured by GDP. Therefore, financial assets prices can be used to estimate the economic activity growth.

Since then, several studies have been engaged, to examine this relationship, such as Barro (1990), Chen (1991), Fama (1990), Lee (1992), Schwert (1990 )...they have concluded that much annual and quarterly stock returns 
fluctuations can be explained by the future estimations of real economic activity in the United States. Peiro (1996) confirmed these results in several industrialized economies, using changes in asset prices instead of yields. Furthermore, Domian and Louton (1997) have demonstrated the existence of an asymmetry in the predictability of economic growth through the stock returns. According to these authors, a negative stock return is followed by a decrease on a greater extent in the economic activity growth rate. In contrast, a low increase in the economic activity growth rate induces a positive change but in a greater extent of stock returns. These conclusions were also supported by Estrella and Mishkin (1996), who concluded that variations in stock returns are more effective in predicting recession economic cycles, including a horizon of three quarters of the year.

However, as Fama (1990) pointed, real activity change is not the only source of stock returns one. Indeed, there are three sources for this change: first, the market reaction to any anticipated cash flow based on GDP growth rate or industrial production (which is used as a proxy). Then, market reaction related to changes in the actualization rate, used to estimate the cah flow. Finally, the anticipated change in yields due to the change in time of the actualization rate. Indeed, Chen (1991), Fama (1990) consider that variations in expected returns are assumed to be estimated on the basis of variables such as dividend or interest rates spread.

Furthermore, Binswanger (2004) tested whether the classical relationship between the real and the financial sphere remains valid for a time horizon greater than the period of two years, which has been highlighted by previous research, especially during the period of recession that characterized the late 20th century. Indeed, all studies have focused on clearly distinct periods (1954-1986 Chen, Fama 1953-1987, 1947-1987 and Lee Schwert: 1889-1988). So, Binswanger (2004) chose a study period that ranges from 1953 to 1997. The author has confirmed the findings of Fama (1990) to the United States, noting that much of the variation in asset returns can be explained by the future value of anticipated or actual economic activity growth.

\section{Methodology}

With reference to Binswanger studies $(2000,2004)$ for the $\mathrm{G} 7$ countries, the analysis of the relationship between the real and the financial spheres can be done through the study of the relationship between the dividend yield rate and the real economic activity growth rate. In our test, we will initially study cointegration between dividend yield rate and real economic activity growth rate (GDP), then we will use the Vector Error Correction Model (VECM) to identify short and long run dynamics between the studied variables.

The disconnection between real and financial spheres has been confirmed in the American and G7 countries with Binswanger's study. Consequently, our analysis will be limited to the Tunisian context as an emerging country case.

The retained variables in our empirical analysis expressed in natural logarithm are the real stock returns rate (stock market index returns) and GDP growth rate (real economic sphere indicator), on an annual basis. The study period runs from 1969 until the year 2008.

[Insert Table 1 here]

The logarithm of price has a mean of 3.41 and a standard deviation of 0.46 with a fluctuation between a maximum of 4.21 and a minimum of 2.65. The GDP logarithm shows an average of 8.94 and a standard deviation of 1.24. The coefficient of symmetry (Skewness) and of flatness (kurtosis) are different from those of a normal distribution. The Jarque-Bera statistic cannot reject the hypothesis of a normal distribution for both series.

\section{Highlighting the disconnection between the real and the financial sphere}

\subsection{Cointegration test}

Before applying the cointegration test, it is wise to test first, the stationarity of the series. Our results based on the Phillips-Perron test, note the existence of a unit root in the series. So we deduce that both series are integrated of order one I (1) or stationary in first difference.

\section{[Insert Table 2 here]}

We conclude that the logarithm of prices is not stationary in level but stationary in first difference.

[Insert Table 3 here]

The GDP logarithm is not stationary in level but stationary in first difference. The cointegrating regression residue is not stationary at 5\% level. Indeed, the t-Statitic for Phillips-Perron tests is equal to -1.688 . The critical value, tabulated by MacKinnon (1991), is -3.3377 at the 5\% level. Therefore, since the computed value exceeds the critical one (-1.688759> -3.3377), the null hypothesis of a cointegrating relationship is rejected at the 5\% significance level, so the GDP logarithm and log prices are not Engle and Granger (1987)'s cointegrated. 
The GDP logarithm, as the variable representing real economic activity, is not stationary in levels but stationary in first difference. Therefore, we can assume that the GDP logarithm is integrated of order one, that we note I (1). The real price logarithm is not stationary in level but stationary in first difference. Therefore, it is integrated of order one I (1).

The presence of unit root in log prices and real GDP is consistent with results obtained by Binswanger (2000, 2004a) in his studies on the most industrialized countries of G7.

The cointegration test between the two variables studied can be conducted either by the Johansen approach (1992, 1995), or through the two-stage test of Engle and Granger (1987). As part of our analysis, we apply the two cointegration tests of Johansen (1992, 1995) (Choi et al (1999), Kwon and Shin (1999) and Rapache (2001)) and Engle and Granger (1987) (Cheung and Ng (1998) and Jafari and Strauss (2000)).

The cointegration test under the Johansen $(1992,1995)$ uses a vector specification error correction introducing $k$ lags as follows:

$$
\Delta \mathrm{z}_{\mathrm{t}}=\mathrm{a}+\mathrm{bd}_{\mathrm{t}}+\Pi \mathrm{z}_{\mathrm{t}-1}+\sum_{\mathrm{i}=1}^{\mathrm{k}-1} \Gamma_{\mathrm{i}} \Delta \mathrm{z}_{\mathrm{t}-\mathrm{i}}+\varepsilon_{\mathrm{t}}
$$

Where, $z_{t}$ a vector of order $(2 \times 1)$ variables integrated of order one. The cointegration test in two stages test is based on estimating the following regression:

$$
\begin{gathered}
\mathrm{x}_{\mathrm{t}}=\mathrm{a}+\mathrm{bp}_{\mathrm{t}}+\mu_{\mathrm{t}} \\
\Delta \mu_{\mathrm{t}}=\mathrm{c} \mu_{\mathrm{t}-1}+\sum_{\mathrm{i}=1}^{\mathrm{k}} \mathrm{d}_{\mathrm{i}} \Delta \mu_{\mathrm{t}-\mathrm{i}}+\theta_{\mathrm{t}}
\end{gathered}
$$

Where,

$\mathrm{x}_{\mathrm{t}}$ and $\mathrm{p}_{\mathrm{t}}$ respectively denote the logarithm of real activity and of the stock prices;

$k$ is the number of lags included in the model;

$\mu_{\mathrm{t}}$ and $\theta_{\mathrm{t}}$ are error terms.

[Insert Table 3 here]

In the sense of Engle and Granger (1987), cointegration regression residuals are not stationary at the 5\% significance level, but stationary at $10 \%$. Therefore, the log GDP and the log prices are not cointegrated in the sense of Engle and Granger (1987) at 5\%. To further refine our findings, it is convenient to refer to cointegration test in the sense of Johansen $(1992,1995)$; results are reported in the following table:

[Insert Table 4 here]

The trace test indicates the existence of one cointegration relationships between the logarithm of GDP and of prices. For a better understanding of the dynamics of short and long term variables studied, it is appropriate to apply the technique of error correction. These results demonstrate the disconnection between the sustainable real economy and the financial sphere in the short run, but in the long run, there is a balance between the real and the financial sphere. To further refine the econometric analysis between the real and the financial sphere, we apply a test that uses Vector Error Correction Model.

\subsection{The Vector Error Correction Model}

Initially introduced by Sargan (1964) and extended by Davidson et al (1978), the Vector Error Correction Model (VECM) allows modeling adjustments that lead to a long-run equilibrium situation. The VECM has cointegration relations built into the specification, so that it restricts the long-run behavior of the endogenous variables to converge to their cointegrating relationships while allowing short-run adjustment dynamics. The cointegration term is known as the error correction term, since the deviation from long-run equilibrium is corrected gradually through series of partial short-run adjustments. It consists on a dynamic model that incorporates simultaneously short and long term dynamics. More formally, for two cointegrated variables, Vector Error Correction Model (VECM) is presented as follows: 


$$
\begin{array}{r}
\Delta \mathrm{X}_{\mathrm{t}}=\gamma_{1} \mathrm{z}_{\mathrm{t}-1}+\sum_{\mathrm{i}} \beta_{\mathrm{i}} \Delta \mathrm{X}_{\mathrm{t}-\mathrm{i}}+\sum_{\mathrm{j}} \delta_{\mathrm{j}} \Delta \mathrm{Y}_{\mathrm{t}-\mathrm{j}}+\mathrm{d}_{1}(\mathrm{~L}) \varepsilon_{\mathrm{X}_{\mathrm{t}}} \\
\Delta \mathrm{Y}_{\mathrm{t}}=\gamma_{2} \mathrm{z}_{\mathrm{t}-1}+\sum_{\mathrm{i}} \alpha_{\mathrm{i}} \Delta \mathrm{X}_{\mathrm{t}-\mathrm{i}}+\sum_{\mathrm{j}} \lambda_{\mathrm{j}} \Delta \mathrm{Y}_{\mathrm{t}-\mathrm{j}}+\mathrm{d}_{1}(\mathrm{~L}) \varepsilon_{\mathrm{Y}_{\mathrm{t}}}
\end{array}
$$

Where:

$\varepsilon_{X_{t}}$ and $\varepsilon_{Y_{t}}$, are two white noises;

$\mathrm{z}_{\mathrm{t}}=\mathrm{X}_{\mathrm{t}}-\mathrm{aY} \mathrm{Y}_{\mathrm{t}}$, designs the cointegration relation residue between $\mathrm{X}$ and $\mathrm{Y}$.

The coefficients $\gamma_{i}$ represent the retraction force to long term target, given by the cointegration relationship. We

must have $\gamma_{\mathrm{i}} \prec 0$ for $i=1$ and 2 and $\left|\gamma_{1}\right|+\left|\gamma_{2}\right| \neq 0$, otherwise there will be no mean reversion to equilibrium

behavior.

Given the two relations (5) and (6), the Vector Error Correction Model allows to integrate the short-term dynamics (represented by the variables in first difference) and the long-term dynamics (represented by the cointegration relationship residue). The application of Vector Error Correction Model to our variables leads to the following results:

[Insert Table 5 here]

The table shows the results of the Vector Error Correction Model. The number of time lags is determined using the Akaike Information Criterion (AIC). Thus, the lags are chosen such as to minimize AIC. The coefficients $\gamma_{i}$ of retraction force to the long-term target in relations (5) and (6) are all under zero (-0.039530 and -0.023288$)$. In addition, the absolute values sum of coefficients $(0.023288+0.039530)$ equals 0.062818 . According to these results, there is a mean reversion to equilibrium behavior. A long-term imbalance between the real and the financial sphere are balanced so that both series have similar trends.

\section{Conclusion}

Our results confirm the existence of disconnection, at least in the short run, between the real and financial spheres. The two series (log (prices) and $\log (\mathrm{GDP})$ ) are not stationary but cointegrated. The Vector Error Correction Model indicates that there is a strong reversion to the long-run target: in short run, the financial sphere is not supported by real basis. So we can argue the disconnection between the two spheres. Such disconnection leads us to conclude that Tunisian stock market is not efficient and that stock prices do not depend on economic fundamentals, but they are the consequence of a speculative investor's behavior. This conclusion corroborates that reported by Binswanger $(2000,2004 a)$ in his studies on the United States and other most industrialized countries of the G7 group. It should be noted that this disconnection found between the real and the financial spheres, is the main argument which encouraged the emergence of speculative bubbles theory (Blanchard and Watson (1982) Fung (1999a, 1999b), Norden and Schaller (2002), Evans (1991) and Fukuta (1998)). These results lead us to wonder whether such a disconnection could indicate the existence of a speculative bubble in the Tunisian stock exchange market and so whether this bubble is rational or irrational. After the recent economic and financial crisis of October 2008 , the question of the inadequacy between real and financial spheres has more and more interested researchers to find explanation of the crisis and to prevent a future occurrence of it. Moreover, the regulation theory has submerged in order to avoid excessive risk-taking and to reduce this disconnection between the two spheres. We suggest to pay more attention to these subjects and to drive reflections around this interesting and crucial purpose that is the imbalance between finance and real activities.

\section{References}

Allen F., and D. Gale. (1992). Stock Price Manipulation. Review of Financial Studies, 5, 503-29.

Allen F., and D. Gale. (2000a). Bubbles and Crises. Economic Journal, 110, 236-55.

Allen F., and D. Gale. (2000b). Comparing Financial Systems. MIT Press, Cambridge, Ms.

Allen F., and G. Gorton. (1993). Churning Bubbles. Review of Economic Studies, 60, 813-36.

Allen F., S. Morris and A Postlewaite. (1993). Finite Bubbles with Short Sale Constraints and Asymmetric Information. Journal of Economic Theory, 61, 206-29. 
Bernanke, B., \& Blinder, A. (1992). The federal funds rate and the channels of monetary transmission. American Economic Review, 82, 901-921.

Bernanke, B., \& Mihov, I. (1995). Measuring monetary policy. NBER Working Paper No. 5145, Cambridge, MA Binswanger M. (1999). Stock Markets, Speculative Bubbles and Economic Growth. Edward Elgar PublishingLtd., MA, USA.

Binswanger, M. (2000). Stock market booms and real economic activity: Is this time different?. International Review of Economics and Finance, 9, 387-415.

Black, F. (1986). Noise. Journal of Finance, 41 (3), 529-43.

Black, F., and Perold, A. F. (1992). Theory of Constant Proportion Portfolio Insurance. Journal of Economic Dynamics and Control, (16,) 403-426.

Blanchard O.J. (1979). Speculative Bubbles, Crashes and Rational Expectations. Economic Letters, 3: $387-89$.

Blanchard, O.J., and Watson, M. (1982). Bubbles, Rational Expectations and Financial Markets. In P. Wachtel (Ed.), Crises in the Economic and Financial Structure, 295-315. Lexington, MA: Lexington Books.

Campbell, J., \& Shiller, R. (1998). Valuation ratios and the long-run stock market outlook. Journal of Portfolio Management, 24, 11-26.

Chen, N. F. (1991). Financial investment opportunities and the macroeconomy. Journal of Finance, 46, $529-554$.

Cochrane, J. (1997). Where is the market going? Uncertain facts and novel theories. Economic Perspectives, 21, 3-37.

Coles, J. L., U. Loewenstein and J. Suay (1995). On Equilibrium Pricing Under Parameter Uncertainty. Journal of Financial and Quantitative Analysis, 30, 347-364.

Cox, J., Ingersoll, J., \& Ross, S. (1985). An intertemporal general equilibrium model of asset prices. Econometrica, 53, 363-384.

De-Bondt W., and R. Thaler. (1987). Further Evidence on Investor Overreaction and Stock Market Seasonality. Journal of Finance, 42: 557-81.

De-Long, B., A. Shleifer, L. Summers and R. Waldmann. (1990). Noise Trader Risk in Financial Markets. Journal of Political Economy, 98: 703-38.

Dothan, M., and D. Feldman. (1986). Equilibrium Interest Rates and Multi-period Bonds in a Partially Observable Economy. The Journal of Finance, 41, 369-382.

Evans, W. G., and S. Honkapohja. (2001). Learning and Expectations in Macroeconomics. Prinston University Press.

Fama, E. (1981). Stock returns, real activity, inflation, and money. American Economic Review, 71, 545-565.

Fama, E. (1990). Stock returns, expected returns, and real activity. Journal of Finance, 45, 1089-1108.

Fama, E., \& French, K. (1989). Business conditions and expected returns on stocks and bonds. Journal of Financial Economics, 25, 23-49.

Flood, R. and Garber, P. (1980). Market Fundamentals Versus Price-Level Bubbles: The first Tests. Journal of Political Economy.

Grossman, S. J. (1988a). Program Trading and Futures Price Volatility. Journal of Futures Markets, Vol. 8 Iss. 4 , pp. 413-419.

Grossman, S. J. (1988b). An Analysis of the Implications for Stock and Futures Price Volatility of Program Trading and Dynamic Hedging Strategies. Journal of Business, Vol. 61, Iss. 3, pp. 275-298.

Grossman. S. J., and Villa, J.L. (1989). Portfolio Insurance in Complete Markets: A note. Journal of Business, 62, 4. 473-76.

Kent, D., D. Hirshleifer and A. Subrahmanyam. (1998). A Theory of Overconfidence, Self-Attribution, and Securities Markets Under and Over Reactions. Journal of Finance.

Keynes, J.M. (1930). A Treatise on Money. London: Macmillan.

Kurz, M. (1996). Rational Preferences and Rational Beliefs., 339-361, in Arrow, J. K., E. Colombatto, and M. Perlman (Eds.), The Rational Foundations of Economic Behaviour. (1996), Macmillan Press Ltd., London. 
Kurz, M. (1997). Endogenous Economic Fluctuations: Studies in the Theory of Rational Belief. Studies in Economic Theory No. 6, Berlin and New York: Springer-Verlag.

Kurz, M. (1994a). On Rational Beliefs Equilibria. Economic Theory, 4, 859-876.

Kurz, M. (1994b). On the Structure and Diversity of Rational Beliefs. Economic Theory, 4, 877-900.

Kyle, A. (1985). Continuous Auctions and Insider Trading. Econometrica, Vol. 53, pp. 1315-1336.

Leland, H. E. (1980).Who Should Buy Portfolio Insurance? Journal of Finance, (May) 35, 581-94.

Levy, M., Levy, H., and Solomon, S. (2000). Microscopic Simulation of Financial Markets: From Investor Behavior to Market Phenomena. Academic Press, 2000.

MacKinnon, James G. (1991). Critical Values for Cointegration Tests, in Long-Run Economic Relationships. R.F. Engle and C.W.J. Granger (eds.), London, Oxford, 267-276.

Mankiw, G., \& Zeldes, S. (1991). The consumption of stockholders and non-stockholders. Journal of Financial Economics, 29, 97-112.

Merton, R. C. (1969). Lifetime Portfolio Selection Under Uncertainty: The Continuous- Time Case. The Review of economics and Statistics, 51, Aug. 1969, 247-57.

Merton, R. C. (1971). Optimum Consumption and Portfolio Rules in a Continuous-Time Model. Journal of Economic Theory, 3, 373-413.

Merton, R. C. (1973). An Intertemporal Capital Asset Pricing Model. Econometrica, 41 (September): 867-87.

Ross, S.A. (1975). Uncertainty and the Heterogeneous Capital Good Model. Review of Economic Studies, 42, 1, Jan. 133-146.

Samuelson, P.A. (1969). Lifetime Portfolio Selection by Dynamic Stochastic Programming. Review of Economics and Statistics, 51, Aug. 239-46.

Sandroni, A. (2000). Do Markets Favor Agents Able to Make Accurate Predictions?. Econometrica, 68, Nov. 1303-1341

Sargent, T. J. (1993). Bounded Rationality in Macroeconomics. Oxford University Press, Oxford, UK.

Shapiro, M. (1988). The stabilization of the U.S. economy: evidence from the stock market.., American Economic Review, 78, 1067-1079.

Shiller, R. (1995). Comment on Poterba, James and Andrew Samwick, 1995, stock ownership patterns, stock market fluctuations and consumption. Brookings Papers on Economic Activity, 2, 359-364.

Shiller, R.J. (1981). Do Stock Prices Move Too Much to be Justified by Subsequent Changes in Dividends? American Economic Review, 71 (3), 421-36.

Summers, L. H. (1986). Does the Stock Market Rationally Reflect Fundamental Values?. Journal of Finance, 41, 591-601.

Tirole, J. (1982). On the Possibility of Speculation Under Rational Expectations. Econometrica, 50. $1163-81$. 
Table 1. Descriptive statistics

\begin{tabular}{lcc}
\hline \hline & LOG(P) & LOG(GDP) \\
\hline \hline Mean & 3.416855 & 8.945650 \\
Median & 3.268883 & 9.117495 \\
Maximum & 4.215515 & 10.55093 \\
Minimum & 2.656578 & 6.518040 \\
Std. Dev. & 0.462362 & 1.248231 \\
Skewness & 0.303178 & -0.438138 \\
Kurtosis & 1.922803 & 1.956494 \\
Jarque-Bera & 2.546702 & 3.094603 \\
Probability & 0.279892 & 0.212821 \\
Sum & 136.6742 & 357.8260 \\
Sum Sq. Dev. & 8.337381 & 60.76513 \\
Observations & 40 & 40 \\
\hline
\end{tabular}

Table 2. Testing for stationarity $: \log (\mathrm{P})$

\begin{tabular}{|c|c|c|c|}
\hline Log (P): level & & Adj. t-Stat & Prob.* \\
\hline Phillips-Perron test statistic & & -0.830027 & 0.3499 \\
\hline \multirow{3}{*}{ Test critical values: } & $1 \%$ level & -2.625606 & \\
\hline & $5 \%$ level & -1.949609 & \\
\hline & $10 \%$ level & -1.611593 & \\
\hline \multicolumn{2}{|l|}{$\log (P)$ : first difference } & Adj. t-Stat & Prob.* \\
\hline \multicolumn{2}{|l|}{ Phillips-Perron test statistic } & -3.763909 & 0.0004 \\
\hline \multirow[t]{3}{*}{ Test critical values: } & $1 \%$ level & -2.627238 & \\
\hline & $5 \%$ level & -1.949856 & \\
\hline & $10 \%$ level & -1.611469 & \\
\hline \multicolumn{4}{|c|}{ Testing for stationarity $: \log ($ GDP) } \\
\hline \multicolumn{2}{|l|}{ Log (GDP): level } & Adj. t-Stat & Prob.* \\
\hline \multicolumn{2}{|l|}{ Phillips-Perron test statistic } & 0.027411 & 0.9953 \\
\hline \multirow[t]{3}{*}{ Test critical values: } & $1 \%$ level & -4.211868 & \\
\hline & $5 \%$ level & -3.529758 & \\
\hline & $10 \%$ level & -3.196411 & \\
\hline \multicolumn{2}{|l|}{ Log (GDP): first difference } & Adj. t-Stat & Prob.* \\
\hline \multicolumn{2}{|l|}{ Phillips-Perron test statistic } & -7.259774 & 0.0000 \\
\hline \multirow[t]{3}{*}{ Test critical values: } & $1 \%$ level & -4.219126 & \\
\hline & $5 \%$ level & -3.533083 & \\
\hline & $10 \%$ level & -3.198312 & \\
\hline
\end{tabular}


Table 3. Testing for cointegration :The Engle-Granger test

$\mathrm{LOG}(\mathrm{GDP})=\mathrm{C}(1)+\mathrm{C}(2) * \mathrm{LOG}(\mathrm{P})$

\begin{tabular}{lcccr}
\hline \multicolumn{1}{r}{ Variable } & Coefficient & \multicolumn{1}{c}{ Std. Error } & t-Statistic & Prob. \\
\hline \hline \multicolumn{1}{c}{$\mathrm{C}(1)$} & 3.745350 & 0.735402 & 5.092932 & 0.0000 \\
$\mathrm{C}(2)$ & 1.824908 & 0.255850 & 7.132730 & 0.0000 \\
\hline \hline R-squared & 0.578951 & Mean dependent var & & 8.907362 \\
Adjusted R-squared & 0.567572 & S.D. dependent var & & 1.240495 \\
S.E. of regression & 0.815741 & Akaike info criterion & & 2.480480 \\
Sum squared resid & 24.62102 & Schwarz criterion & & 2.565791 \\
Log likelihood & -46.36936 & Hannan-Quinn criter. & & 2.511089 \\
F-statistic & 50.87584 & Durbin-Watson stat & & 0.131437 \\
Prob(F-statistic) & 0.000000 & & \\
\hline \hline
\end{tabular}

Testing for stationarity

Null Hypothesis: RESID01 has a unit root

\begin{tabular}{lccc}
\hline \hline & & Adj. t-Stat & Prob.* \\
\hline \hline Phillips-Perron test statistic & & -1.688759 & 0.0860 \\
\hline Test critical values: & $1 \%$ level & -2.625606 & \\
& $5 \%$ level & -1.949609 & \\
& $10 \%$ level & -1.611593 & \\
\hline \hline
\end{tabular}

Table 4. Johansen Cointegration Test

Date: 03/18/10 Time: 11:18

Sample (adjusted): 19712008

Included observations: 38 after adjustments

Trend assumption: No deterministic trend (restricted constant)

Series: LOG(GDP) LOG(P)

Lags interval (in first differences): 1 to 1

Unrestricted Cointegration Rank Test (Trace)

\begin{tabular}{ccccc}
\hline \hline $\begin{array}{c}\text { Hypothesized } \\
\text { No. of CE(s) }\end{array}$ & Eigenvalue & $\begin{array}{c}\text { Trace } \\
\text { Statistic }\end{array}$ & $\begin{array}{c}0.05 \\
\text { Critical Value }\end{array}$ & Prob.** \\
\hline \hline None * & 0.564041 & 36.60469 & 20.26184 & 0.0001 \\
At most 1 & 0.124599 & 5.056783 & 9.164546 & 0.2773 \\
\hline \hline
\end{tabular}

Trace test indicates 1 cointegrating eqn(s) at the 0.05 level

* denotes rejection of the hypothesis at the 0.05 level

**MacKinnon-Haug-Michelis (1999) p-values 
Unrestricted Cointegration Rank Test (Maximum Eigenvalue)

\begin{tabular}{ccccc}
\hline \hline $\begin{array}{c}\text { Hypothesized } \\
\text { No. of CE }(\mathrm{s})\end{array}$ & Eigenvalue & $\begin{array}{c}\text { Max-Eigen } \\
\text { Statistic }\end{array}$ & $\begin{array}{c}0.05 \\
\text { Critical Value }\end{array}$ & Prob.** \\
\hline \hline None ${ }^{*}$ & 0.564041 & 31.54791 & 15.89210 & 0.0001 \\
At most 1 & 0.124599 & 5.056783 & 9.164546 & 0.2773 \\
\hline \hline
\end{tabular}

Max-eigenvalue test indicates 1 cointegrating eqn(s) at the 0.05 level

* denotes rejection of the hypothesis at the 0.05 level

**MacKinnon-Haug-Michelis (1999) p-values

Unrestricted Cointegrating Coefficients (normalized by $b^{\prime * S} 11 * b=I$ ):

\begin{tabular}{ccc}
\hline \hline LOG(GDP) & LOG(P) & C \\
-0.811982 & 0.101766 & 9.572662 \\
0.654177 & 2.883880 & -15.80763 \\
\hline \hline Unrestricted Adjustment Coefficients (alpha): \\
\hline \hline D(LOG(GDP)) & 0.043894 & 0.000129 \\
D(LOG(P)) & -0.012742 & -0.050154 \\
\hline \hline
\end{tabular}

Normalized cointegrating coefficients (standard error in parentheses)

$\begin{array}{ccc}\text { LOG(GDP) } & \text { LOG(P) } & \text { C } \\ 1.000000 & -0.125330 & -11.78925 \\ & (0.44692) & (1.41335)\end{array}$

Adjustment coefficients (standard error in parentheses)

$\begin{array}{cc}\mathrm{D}(\mathrm{LOG}(\mathrm{GDP})) & -0.035641 \\ & (0.00530) \\ \mathrm{D}(\mathrm{LOG}(\mathrm{P})) & 0.010347 \\ & (0.01956)\end{array}$


Table 5. Vector Error Correction estimation Output

\begin{tabular}{|c|c|c|}
\hline Cointegrating Eq: & CointEq1 & \\
\hline \multirow{4}{*}{$\begin{array}{l}\text { LOG(GDP(-1)) } \\
\text { LOG(P(-1)) }\end{array}$} & 1.000000 & \\
\hline & -0.156095 & \\
\hline & $(0.44586)$ & \\
\hline & $(-0.35010)$ & \\
\hline $\mathrm{C}$ & -8.585932 & \\
\hline Error Correction: & $\mathrm{D}(\mathrm{LOG}(\mathrm{GDP}))$ & $\mathrm{D}(\operatorname{LOG}(\mathrm{P}))$ \\
\hline \multirow[t]{3}{*}{ CointEq1 } & -0.039530 & -0.023288 \\
\hline & $(0.01057)$ & $(0.03969)$ \\
\hline & $(-3.73933)$ & $(-0.58669)$ \\
\hline \multirow[t]{3}{*}{$\mathrm{D}(\operatorname{LOG}(\mathrm{GDP}(-1)))$} & -0.175217 & -0.403751 \\
\hline & $(0.17086)$ & $(0.64154)$ \\
\hline & $(-1.02550)$ & $(-0.62934)$ \\
\hline \multirow[t]{3}{*}{$\mathrm{D}(\operatorname{LOG}(\mathrm{GDP}(-2)))$} & 0.098497 & -0.038001 \\
\hline & $(0.16753)$ & $(0.62903)$ \\
\hline & $(0.58795)$ & $(-0.06041)$ \\
\hline \multirow[t]{3}{*}{$\mathrm{D}(\operatorname{LOG}(\mathrm{P}(-1)))$} & -0.009229 & 0.431900 \\
\hline & $(0.04749)$ & $(0.17832)$ \\
\hline & $(-0.19433)$ & $(2.42200)$ \\
\hline \multirow[t]{3}{*}{$\mathrm{D}(\mathrm{LOG}(\mathrm{P}(-2)))$} & 0.015767 & -0.143173 \\
\hline & $(0.04754)$ & $(0.17852)$ \\
\hline & $(0.33162)$ & $(-0.80200)$ \\
\hline \multirow[t]{3}{*}{$\mathrm{C}$} & 0.109558 & 0.070691 \\
\hline & $(0.02807)$ & $(0.10538)$ \\
\hline & (3.90354) & $(0.67080)$ \\
\hline & 0.519055 & 0.170732 \\
\hline Adj. R-squared & 0.441484 & 0.036979 \\
\hline Sum sq. resids & 0.056167 & 0.791872 \\
\hline S.E. equation & 0.042566 & 0.159826 \\
\hline F-statistic & 6.691300 & 1.276471 \\
\hline Log likelihood & 67.57073 & 18.61833 \\
\hline Akaike AIC & -3.328148 & -0.682072 \\
\hline Schwarz SC & -3.066918 & -0.420842 \\
\hline Mean dependent & 0.101885 & 0.033121 \\
\hline S.D. dependent & 0.056956 & 0.162865 \\
\hline \multicolumn{2}{|l|}{ Determinant resid covariance (dof adj.) } & $4.59 \mathrm{E}-05$ \\
\hline \multicolumn{2}{|l|}{ Determinant resid covariance } & $3.22 \mathrm{E}-05$ \\
\hline \multicolumn{2}{|l|}{ Log likelihood } & 86.32917 \\
\hline \multicolumn{2}{|l|}{ Akaike information criterion } & -3.909685 \\
\hline \multicolumn{2}{|l|}{ Schwarz criterion } & -3.300148 \\
\hline
\end{tabular}

